\title{
Removal Site Evaluation Report on Building 3019B at Oak Ridge National Laboratory, Oak Ridge, Tennessee
}
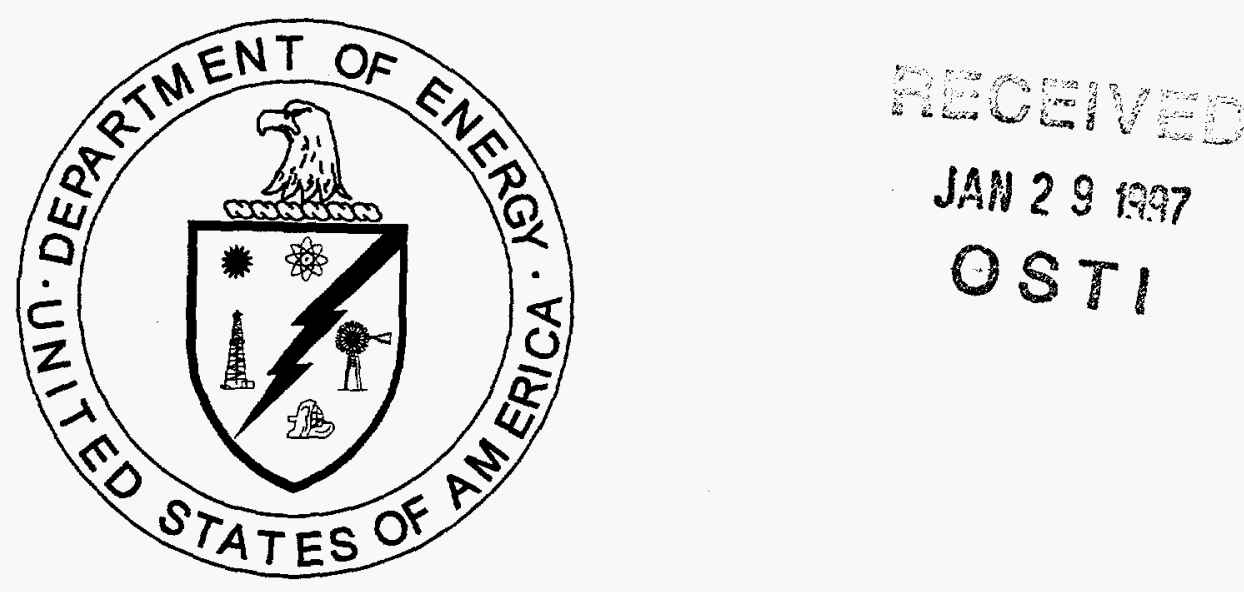

DISCLAIMER

This report was prepared as an account of work sponsored by an agency of the United States Government. Neither the United States Government nor any agency thereof, nor any of their employees, makes any warranty, express or implied, or assumes any legal liability or responsibility for the accuracy, completeness, or usefulness of any information, apparatus, product, or process disclosed, or represents that its use would not infringe privately owned rights. Reference herein to any specific commercial product, process, or service by trade name, trademark, manufacturer, or otherwise does not necessarily constitute or imply its endorsement, recommendation, or favoring by the United States Government or any agency thereof. The views and opinions of authors expressed herein do not necessarily state or reflect those of the United States Government or any agency thereof.

This document has been approved by the ORNL Technical Information Office for release to the public. Date: $9 / 12 / 96$ 


\section{Advanced Sciences, Inc.}

contributed to the preparation of this document and should not be considered an eligible contractor for its review.

This report has been reproduced directly from the best available copy.

Available to DOE and DOE contractors from the Office of Scientific and Technical Information, P.O. Box 62, Oak Ridge, TN 37831; prices available from 423-576-8401 (fax 423-576-2865).

Available to the public from the National Technical Information Service, U.S. Department of Commerce, 5285 Port Royal Rd., Springfield, VA 22161. 


\section{Energy Systems Environmental Restoration Program \\ Removal Site Evaluation Report on Building 3019B \\ at Oak Ridge National Laboratory, Oak Ridge, Tennessee}

Date Issued—September 1996

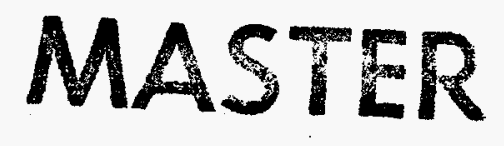

Prepared by

Advanced Sciences, Inc.

Oak Ridge, Tennessee

under subcontract 96B-99311C

Prepared for the

U.S. Department of Energy

Office of Environmental Management

under budget and reporting code EW 70

Environmental Management Activities at OAK RIDGE NATIONAL LABORATORY

Oak Ridge, Tennessee 37831-6285

$$
\text { managed by }
$$

LOCKHEED MARTIN ENERGY SYSTEMS, INC.

for the

U.S. DEPARTMENT OF ENERGY

under contract DE-AC05-84OR21400 



\section{DISCLAIMER}

Portions of this document may be illegible in electronic image products. Images are produced from the best available original document. 


\section{PREFACE}

This document, Removal Site Evaluation Report on Building 3019B at Oak Ridge National Laboratory, Oak Ridge, Tennessee (DOE/OR/01-1514\&D1), constitutes the final phase II remedial site evaluation of Building 3019B and was prepared in accordance with requirements under the Comprehensive Environmental Response, Compensation, and Liability Act of 1980 . This work was performed under Work Breakdown Structure 1.6.6.2.1, "Oak Ridge Reservation," and Activity Data Sheet Number OR6500FT, "Oak Ridge Reservation Facility Transition Program." Publication of this document provides the Environmental Restoration Program with information necessary to evaluate whether hazardous and/or radiological contaminants in and around Building 3019B pose a substantial risk to human health or the environment and if remedial site evaluations or removal actions are required. 



\section{CONTENTS}

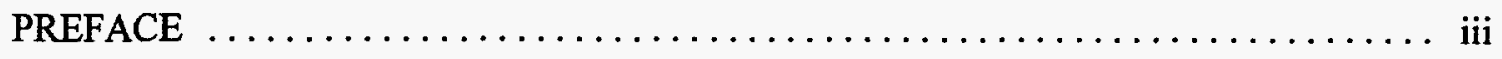

ABBREVIATIONS $\ldots \ldots \ldots \ldots \ldots \ldots \ldots \ldots \ldots \ldots \ldots \ldots \ldots \ldots \ldots \ldots \ldots \ldots \ldots \ldots \ldots$

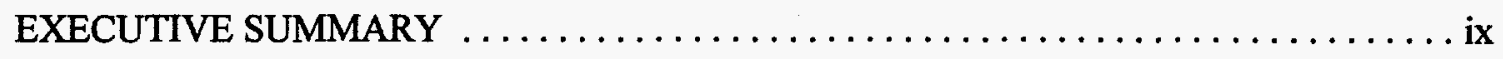



2. SUMMARY OF REMOVAL SITE EVALUATION $\ldots \ldots \ldots \ldots \ldots \ldots \ldots \ldots \ldots$.

3. BUILDING 3019B INFORMATION FORM .............. 3-1 


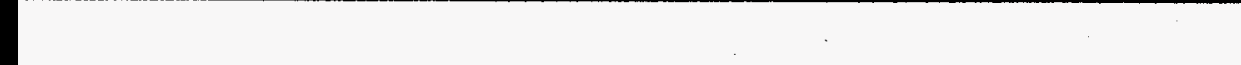




\section{ABBREVIATIONS}

$\begin{array}{ll}\text { ACM } & \text { asbestos-containing material } \\ \text { CFR } & \text { Code of Federal Regulations } \\ \text { D\&D } & \text { Decontamination and Decommissioning } \\ \text { DOE } & \text { U.S. Department of Energy } \\ \text { ER } & \text { Environmental Restoration (Program) } \\ \text { HAZMAT } & \text { hazardous material } \\ \text { HEPA } & \text { high-efficiency particulate air (filter) } \\ \text { HRFDP } & \text { High Ranking Facilities Deactivation Project } \\ \text { LBP } & \text { lead-based paint } \\ \text { LLLW } & \text { liquid low-level (radioactive) waste } \\ \text { LMES } & \text { Lockheed Martin Energy Systems, Inc. } \\ \text { LWBR } & \text { Light Water Breeder Reactor } \\ \text { MTR } & \text { Metals Testing Reactor } \\ \text { ORNL } & \text { Oak Ridge National Laboratory } \\ \text { PCB } & \text { polychlorinated biphenyl } \\ \text { PUREX } & \text { plutonium and uranium extraction process } \\ \text { RAD } & \text { radiologic } \\ \text { RCRA } & \text { Resource Conservation and Recovery Act } \\ \text { RmSE } & \text { removal site evaluation } \\ \text { S\&M } & \text { surveillance and maintenance } \\ \text { TCLP } & \text { Toxicity Characteristic Leaching Procedure } \\ \text { THOREX } & \text { Thorium Extraction Program } \\ \text { WAG } & \text { waste area grouping } \\ \text { WOC } & \text { White Oak Creek }\end{array}$




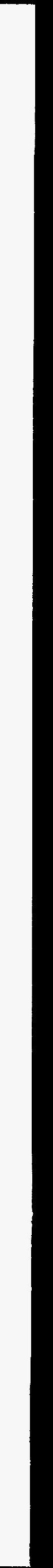




\section{EXECUTIVE SUMMARY}

This removal site evaluation report on Building 3019B at Oak Ridge National Laboratory was prepared to provide the Environmental Restoration Program with information necessary to evaluate whether hazardous and/or radiological contaminants in and around the facility pose a substantial risk to human health or the environment (i.e., a high probability of adverse effects) and whether remedial site evaluations or removal actions are, therefore, required. The scope of the project included (1) a search for, and review of, readily available historical records regarding operations and use of the facility (including hazardous substance usage and existing contamination); (2) interviews with facility personnel concerning current and past practices; and (3) a brief walk-through to visually inspect the facility and identify existing hazard areas requiring maintenance actions or remedial evaluation.

The results of the removal site evaluation indicate that areas inside Building 3019B pose no imminent hazard because adequate engineering and administrative controls are in place and enforced within the facility to ensure worker and environmental protection. A maintenance action, however, is being undertaken or proposed.

Deteriorated and peeling exterior paint in areas on the west and south walls on the exterior of the building has an uninhibited pathway to the storm water drainage system and can potentially impact the local surface water during periods of storm water runoff. The paint is assumed to be lead based, thus posing a potential problem. In addition, the subsurface of all of the exterior walls may be radiologically contaminated. A maintenance action will be necessary to prevent further deterioration and dislodging of the paint.

The recommended corrective action is being conducted as a maintenance action planned for completion in FY 1996; accordingly, this removal site evaluation is considered complete and terminated. 


\section{INTRODUCTION}

A removal site evaluation is required by the regulators for all facilities in the Nuclear Material and Facility Stabilization (EM-60) Program included in Appendix C of the Federal Facility Agreement. Between May 20 and May 28, 1996, a removal site evaluation was conducted on Building 3019B, also known as the High Radiation Level Analytical Facility. The scope of the project included (1) a search for, and review of, readily available historical records regarding operations and use of the facility (including hazardous substance usage and existing contamination); (2) interviews with facility personnel concerning current and past practices; and (3) a brief walkthrough to visually inspect the facility and identify existing hazard areas requiring maintenance actions or remedial evaluation. The results of the removal site evaluation are summarized in Sect. 2, and the completed information form is presented in Sect. 3. 


\section{SUMMARY OF REMOVAL SITE EVALUATION}

Building 3019B is currently in a deactivated, standby mode awaiting entry into the Decontamination and Decommissioning (D\&D) Program. Currently, no operations other than surveillance and maintenance (S\&M) are ongoing in this building. The building is accessed periodically by personnel in order to conduct various S\&M activities; otherwise, the building remains secured from public access.

A removal site evaluation was conducted between May 20 and May 28, 1996. No imminent hazard areas requiring maintenance actions were identified inside Building 3019B during this Removal site evaluation. Radiologic (RAD) hazard areas and asbestos-containing materials (ACMs) are marked and isolated as necessary to ensure worker safety and to prevent inadvertent release within the facility. In addition, engineering and administrative controls are in place and enforced within the facility for worker and environmental protection. Current actions being taken to prevent further release of contamination and ensure worker safety within Building 3019B are considered adequate until D\&D activities begin.

The removal site evaluation identified areas outside Building 3019B that may pose an imminent hazard. The age of the facility indicates that the building's paint may contain lead, according to staff in the ORNL Lead Management Program. Exterior paint in areas of the west and south walls is badly deteriorated and peeling off. The surface below these areas is paved, and storm drains are located in the immediate vicinity. As a result, the paint that chips off the building has an uninhibited pathway to the storm water drainage system during rain events. Thus, this paint potentially can have a direct impact on surface water in the local area during periods of storm water runoff. In addition, the subsurface of all exterior walls may be radiologically contaminated as a result of an explosion in Building 3019 during the 1950s. The exterior paint in these areas should be sampled and analyzed to determine the lead content and to assess whether a hazard actually exists. If a hazard does exist, a maintenance action will be necessary to prevent further deterioration and dislodging of the paint. A maintenance action is scheduled to address this recommendation during FY 1996.

With the exception of the exterior paint on Building 3019B, adequate efforts are being made to contain and control existing contamination in order to protect human health and the environment. Given the current status and condition of Building 3019B, this Removal site evaluation is considered complete and terminated according to the requirements for removal site evaluation termination set forth in 40 CFR 300.410(e). 
3. BUILDING 3019B INFORMATION FORM 
ORNL FACILITY RmSE INFORMATION FORM

\section{General Information}

Area/Facility Name

(and aliases): Building 3019B

High Radiation Level Analytical Facility

Organization responsible for arealfacility

(include specific person and phone number if possible):

K. Constant (241-3146), HRFDP Project Manager, ER Program, LMES

\begin{tabular}{|l|l}
\hline Status (active/inactive): $\quad$ Inactive, Standby Mode & Years of Operation: $\approx 30$
\end{tabular}

Description of Operation:

There are no current operations, other than surveillance and maintenance (S\&M) activities, ongoing in this building. Building 3019B was originally constructed in 1950, and operations ceased in 1984. Historically, the facility was used for separating, processing, and analyzing highly radioactive samples in support of many ORNL programs, including the Thorium Extraction (THOREX) Program, the Volatility Program, the Kilorod Program, and the Light Water Breeder Reactor (LWBR) Program. The facility was also involved in the development of the Plutonium Uranium Extraction (PUREX) Process for the separation of plutonium from spent fuel, and the development of the Materials Testing Reactor (MTR). 
Physical description of area/facility:

- Building 3019B is a single-story, concrete and masonry block structure consisting of $3000 \mathrm{ft}^{2}$ of floor space.

- The building is physically connected to Building 3019A to the east and Building 3135 to the northwest and is located in an industrial area of the main plant at ORNL.

- Paint on exterior surfaces of the building is generally in good condition with the exception of localized areas of deterioration on the west and south walls.

- Systems which remain operational in the building include steam, ventilation, fire protection, and electrical service.

- The immediate area surrounding Building 3019B is paved.

- Building 3019B contains a hot cell bank with seven cells and a central storage cell. Zinc-bromide in the hot cell viewing windows has been drained and removed from the facility, and lead shields have been placed over each window. Documentation reviewed during this RmSE indicated that the remaining viewing window in the central storage cell contained zinc-bromide. However, according to the Facility Manager, the configuration of this window consists of layers of lead-impregnated glass filled with mineral oil to enhance visual clarity. The window was observed to be in sound condition during the facility inspection.

- Hot cell drains discharged to the low-level liquid waste (LLLW) system. Building floor drains discharged to the process waste system. Work with radioactive materials was historically performed in the hot cells; however, the cells are currently shut down. According to the drain survey report for Building 3019B, all the liquid waste drains have been plugged and taken out of service.

- The interior of the building is in good condition. Asbestos containing material (ACM) and radiation (RAD) hazard areas are posted and/or labeled as appropriate. Painted surfaces throughout the interior of the facility are in good condition. The roof reportedly leaks slightly during heavy rain events. Facility personnel indicated that a Work Order has been submitted to have this repaired.

- The ventilation system keeps the hot cells under negative pressure relative to the interior of the building and the building under negative pressure relative to atmosphere. The building itself is not sealed.

- A building space diagram is attached to this form showing the locations of the various process areas. 


\section{Release Information}

Description of release, or threatened release, and source:

Low levels of residual fixed and transferable radiologic surface contamination exist in areas of the facility as a result of historical operations. The contamination is located primarily in the hot cells and process equipment (vessels, hoods, piping, ventilation ducts, etc.). This contamination has accumulated from activities involving a variety of materials throughout the operating history of the facility and, therefore, cannot be attributed to a single release episode. Hot cells in this facility have been known to leak radioactive contamination along the rails at the base of the rear access doors. This leakage is reportedly small in quantity and is cleaned up when detected as part of building S\&M. The presence of RAD contamination at existing levels within the facility is not considered a significant hazard in its current state.

Hazardous materials (HAZMATs) (e.g., acids, hydraulic fluids, and other chemicals) were reportedly used in small quantities (i.e., less than 5 gallons or 100 pounds) during facility operations. Currently, all HAZMATs have been removed from the facility. According to available spill/release records and facility personnel interviews, no significant HAZMAT spills (i.e., spills having the potential to adversely affect human health and/or the environment) have been reported for this building. No current conditions were identified which present a potential for a significant HAZMAT release.

Hazardous substances present:

Hazardous substances remaining in Building 3019B consist mainly of residual RAD surface contamination. Areas of fixed and transferable RAD contamination are associated primarily with the hot cells and process equipment. The EM60 Facility Inventory and Assessment Database Asset Data Sheet for Building 3019B indicated that 55 gallons of polychlorinated bi-phenols (PCBs) were stored in the facility. However, the only PCB items identified during the building walk-through and facility personnel interviews were suspect light ballasts in the fluorescent light fixtures. No bulk storage of $\mathrm{PCB}$ fluid was confirmed present in this facility.

Estimate (if possible) of quantities of hazardous substances that have been released and that could be released:

No information regarding quantities of hazardous substances existing in Building 3019B was identified during this RmSE. On the basis of the residual nature of the contamination reportedly present, it is expected that the quantities are small.

\section{Other pollutants or contaminants:}

ACM, primarily in the form of thermal system insulation, has been confirmed present in this building. ACM observed is in good condition and poses no immediate health threat. On the basis of the age of the facility, interior and exterior painted surfaces are assumed to be lead-containing. Verification samples are taken by ORNL Lead Management Program personnel on an "as-needed" basis to confirm the presence of lead in the paint (i.e., when work activities will disturb the paint or when paint is found to be deteriorating and poses a health or environmental threat). Interior painted surfaces observed are in good condition throughout the facility and pose no immediate health threat. Paint on exterior surfaces is chipped and flaking off to the ground below in some areas, particularly on the west and south walls of the building. According to the ORNL Lead Management Office, no verification samples on this paint have been taken and analyzed; therefore, the paint in these areas remains assumed to contain lead. It should be noted that due to an explosion that occurred in Building 3019 during the 1950s, there is a potential for existence of fixed residual RAD contamination under painted surfaces throughout the interior and exterior of the building. Since this paint was applied primarily to fix areas of RAD contamination, the potential also exists for paint chips which peel off the building to contain RAD contaminants. 


\section{Groundwater}

Are there any suspected impacts to groundwater? If yes, please describe. Include any impacts to drinking water sources.

Building 3019B is located in Waste Area Grouping (WAG) 1 at ORNL. Although no specific adverse spills or releases of hazardous substances were identified during this RmSE, it is suspected, based on available environmental studies conducted in WAG 1 , that process and LLLW drains and associated piping may have leaked over the life of the facility. Buried process and LLLW piping and some drains have been found to be deteriorated and leaking in other facilities and areas of WAG 1. Additionally, LLLW lines have been found to be leaking and subsequently mitigated adjacent to the southwest corner of Building 3019B. Studies have determined that groundwater in WAG 1 (including the area of Building 3019) has been both radiologically and chemically contaminated. Numerous man-made radionuclides have been detected in WAG 1 groundwater samples including those processed in Building 3019B (Sr-90, Y-90, Cs-137, Cm-244). It is likely that liquid waste from activities involving radioisotopes in Building 3019B have historically contributed to WAG 1 groundwater contamination. However, the radionuclides detected in the groundwater were common to the processes and activities in many other buildings in the area which makes it difficult to determine exactly which building is, or was, the source of contamination.

Because of the reported small quantities of chemicals historically used in this facility, it is unlikely that such usage has significantly contributed to WAG 1 groundwater contamination. Floor drains are located in each hot cell and in Room 15. As part of the facility shutdown process, process and LLLW drains within the building have been plugged to prevent the potential for further inadvertent release.

Other than the potential for historical impact to groundwater in WAG 1 via leaking process and LLLW lines external to the building, no existing immediate threat to groundwater was identified given the current status of the facility.

\section{Surface Water}

Are there any suspected impacts to surface water? If yes, please describe. Also describe the most likely surface water migration route(s), if applicable. Include any impacts to drinking water sources.

WAG 1 is essentially bound by Fifth Creek to the east, White Oak Creek (WOC) to the south, and First Creek to the west. First and Fifth creeks flow south into WOC, which flows to the west and exits WAG 1 at the southwest corner. Storm water (from surface runoff and storm water drainage system) and treated water from the process waste system discharges into WOC. The only potential for direct impact to surface water from Building 3019B in its current state would be from lead-containing paint chips which fall off the exterior painted surfaces and find their way into the storm water drainage system and eventually to WOC. Exterior paint was found to be severely deteriorated in areas of the west and south walls of the building. The building apron is paved and storm drains are located adjacent to the areas of deteriorating paint. There is a strong potential for peeling paint from these walls to dislodge during a storm event and be carried into the storm water drainage system with rainwater.

Surface water may have also been indirectly impacted by leaking process and LLLW lines external to the building. Some of these lines are known to have shared a common trench with storm water drainage piping. Contamination from leaking waste lines could potentially enter deteriorated storm water piping and migrate to WOC. The three creeks bordering WAG 1 are groundwater discharge points. Therefore, groundwater contaminated by leaking waste lines could also potentially impact surface water in the area.

Other than the potential for historical impact, the only existing immediate threat to surface water identified during this RmSE is that from the assumed lead-containing exterior paint on the west and south walls of the building. 
Air

Are there any suspected impacts due to air emissions? If yes, please describe.

Because of the presence of residual contamination with the hot cells and process equipment, a potential exists for radiation exposure to personnel working inside and within the immediate vicinity of the facility due to potential airborne migration of radioactive particulates and physical contact with contaminated surfaces. Areas of RAD contamination are identified, marked, and controlled as appropriate throughout the facility to protect against inadvertent exposure to personnel. Air in Building 3019B is controlled by the Building 3019 laboratory off-gas ventilation system which exhausts the air through a high efficiency particulate air (HEPA) filter bank before it is discharged to the atmosphere through stack 3020 . The draw of the ventilation system creates a slight negative pressure within the hot cells and interior of Building 3019B; however, the building is not sealed. Apart from catastrophic failure of the hot cells or ventilation system, it is unlikely that radioactive air emissions from Building 3019B would impact personnel or the environment in its current state.

A potential also exists for impact to indoor air quality due to the presence of $A C M$ and assumed lead-based paint (LBP) should these materials be disturbed. The ACM and assumed LBP remaining in the building are not considered to be immediate threats to indoor quality in their current state.

\section{Soil}

Are there any suspected impacts to soil? If yes, please describe.

As stated for groundwater, there is a potential for historical impact to soils in the area of Building 3019B due to leaking process and LLLW drain piping. Previous environmental studies have identified areas of soil contamination in the Building 3019 area and soil samples collected have detected radioisotopes common to the processes performed in Building 3019B. Also, leaking LLLW lines adjacent to the southwest corner of Building 3019B have been mitigated in the past. As a result, it is likely that processes associated with this building have historically contributed to WAG 1 soil contamination.

Because the apron surrounding the facility is paved, it is not likely that soils in the immediate area have been, or will be, impacted by the deteriorating exterior paint if, in fact, the paint is lead-containing.

Other than the potential for historical impact, no existing conditions were identified during this RmSE to be immediate threats to soils in the area of Building 3019B. 
Release Beyond Facility or Reservation Boundaries

Has or will the release migrate beyond the boundaries of the facility or reservation? If yes, please describe (including possible human or environmental receptors).

The following are considered potential scenarios where radiologic contamination could migrate beyond the facility or reservation boundaries:

- A person becomes inadvertently contaminated from residual surface contamination and leaves the facility/reservation undetected.

- Catastrophic failure of the building or contaminated equipment.

There is also a potential for assumed lead-containing paint which peels off the exterior of the building to be carried away from the facility and off-site with surface runoff during a rain event. Since the paint chips have a direct, uninhibited pathway to nearby storm water drains, this potential is considered high.

With the exception of deteriorating exterior paint, the potential for adverse release of contamination beyond the facility or site boundaries is considered slight and unlikely due to the current status and condition of the facility and the engineering/administrative controls that are in place to protect again such an event.

\section{Worker Safety}

Could the release pose a threat to workers? If yes, please describe.

Radiologically contaminated areas are isolated and well marked. Good radiation practices and standard operating procedures governing activities within the facility are enforced for worker safety. Personnel exiting contaminated areas of the facility are required to "frisk" themselves to detect the presence of RAD contamination. Monitors and alarms are in place to detect any radioactive release within the building. ACM is appropriately labeled. The building is located in a secured area and access is controlled through Building 3019A. However, even with these safeguards in place, a potential threat to workers exists if safety measures are overlooked. This potential is not considered significant given the current status and level of activity of the building.

\section{Environmental Receptors}

Does the release pose a potential threat to environmental receptors? If yes, please describe. Include natural resources impacts.

No existing conditions posing an immediate significant threat to environmental receptors, including natural resources, were identified to be currently associated with Building 3019B. 


\section{Mitigation}

What action(s) might be taken to abate/prevent release or impacts from release?

- Continued utilization and enforcement of engineering and administrative controls that are currently in place to protect workers and monitor conditions and activities in the building.

- Exterior paint on the west and south walls of the facility should be tested for lead content. If the paint is found to be lead-containing, a maintenance action will be required to eliminate areas of deteriorating paint. Areas of deteriorating paint are reportedly scheduled for attention during Fiscal Year (FY) 1996.

- The rear access doors to the hot cells should be sealed to prevent further leakage of radioactive contamination, and eliminate the need for periodic cleaning of such material.

- As a matter of housekeeping, the weatherstripping around the north entry door in Room 15 should be repaired to prevent rainwater from leaking into the facility during a storm event. The immediate area inside the door is currently bermed to prevent the water from running into the facility. This situation does not present a potential for contamination migration, but it is a reoccurring problem that could easily be mitigated.

- A Work Order has been submitted to repair a roof leak over the hot cell bank; however, the roof remains unrepaired. This Work Order should be executed as soon as possible to prevent further leakage of rainwater into the facility during a storm event. Reportedly, the roof is scheduled for repair during FY 1996.

- Continue S\&M activities per Procedure IP-900.

What actions are currently being taken to abate/prevent release or impacts from release?

Engineering and administrative controls are in place to control access to the facility and contaminated areas, and to monitor conditions and activities within the facility for worker and environmental protection. Warning signs and labels are posted throughout the facility indicating RAD and ACM hazard areas. Standard operating procedures are in place for building access and S\&M activities to protect against inadvertent contact and disturbance of contaminated areas and materials. The building is periodically monitored for areas of RAD contamination by ORNL health physics personnel.

What actions are currently being taken to abate/prevent release or impacts from release? (Continued)

Personnel are "frisked" upon exit of contaminated areas of the facility to detect the presence of radiologic contamination. The building is currently under deactivation and is in S\&M status awaiting entry into the Decontamination and Decommissioning (D\&D) Program. The ventilation, fire protection, electrical, and steam heating systems remain operational to maintain current conditions in the facility and prevent inadvertent contamination discharge. The building is inspected periodically for structural changes and degradation which include any cracking, failure, or deterioration of the facility and/or equipment that may allow contamination to be released.

Current actions being taken to prevent further release and ensure worker safety in Building 3019B are considered adequate until $\mathrm{D} \& \mathrm{D}$ activities begin. 


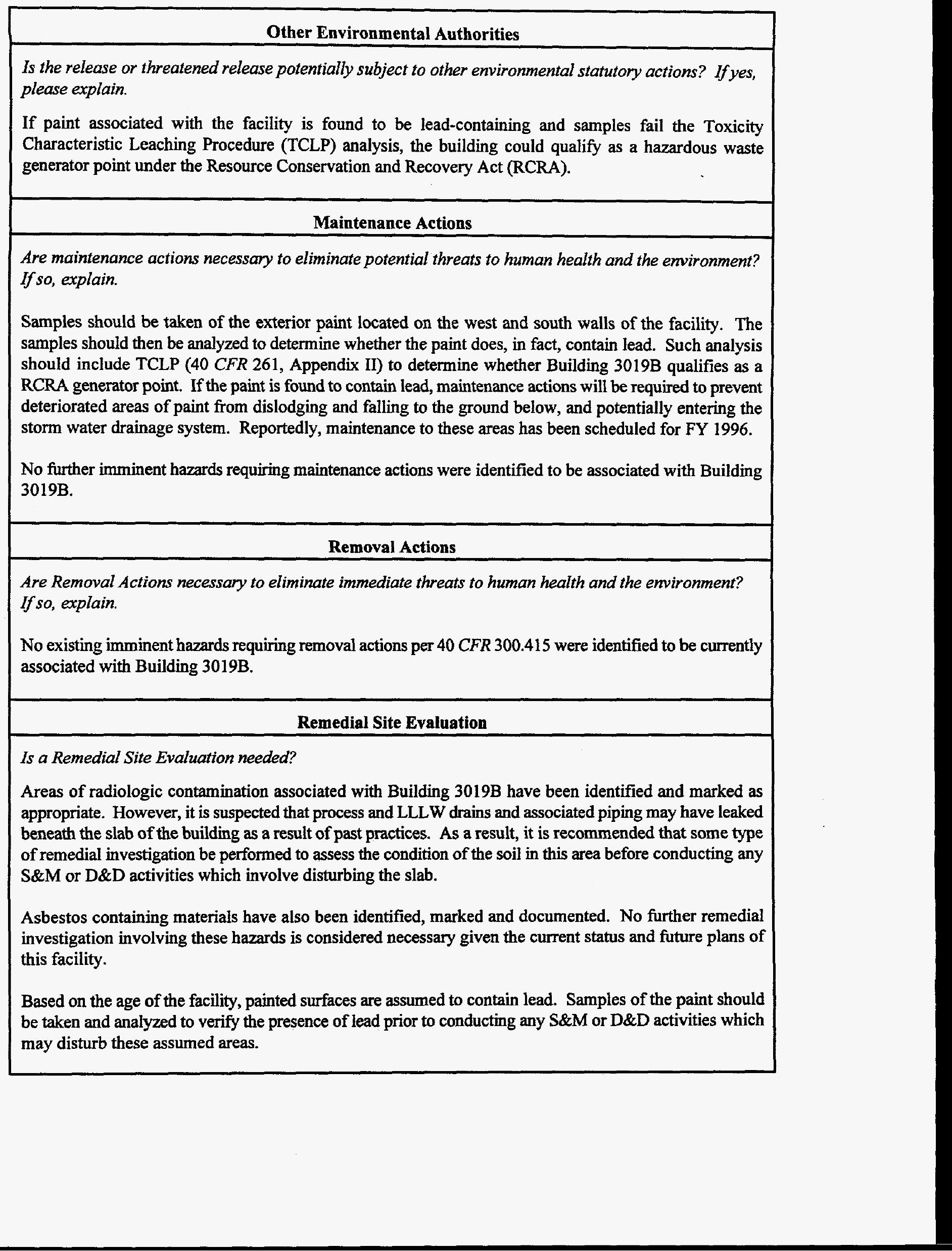


No Further Investigation

Is a finding of No Further Investigation appropriate? Please explain.

A finding of No Further Investigation implies that a facility or area is free from hazardous substances or contaminants that may threaten human health and the environment. Since Building 3019B contains substances and materials which may become threatening if not properly controlled, handled and managed during the S\&M cycle, a finding of No Further Investigation is inappropriate in this case.

\section{Additional Comments}

The following documents and databases were referenced for historical and hazard information related to Building 3019B:

- Work Plan for the High Ranking Facilities Deactivation Project at Oak Ridge National Laboratory, Document No. ORNL/ER-322.

- ORNL Hazardous Material Information System Database.

- ORNL PCB Inventory Database.

- EM60 Facility Inventory and Assessment Database.

- Portions of Drain Survey Report for Building 3019 (A\&B).

The following personnel and offices were contacted and provided historical and current use/condition information for Building 3019B:

- $\quad$ Ms. J. M. Butler, Supervisor, Building 3019.

- Mr. A. M. Krichinsky, Facility Manager, Building 3019.

- Ms. Swati Wilson, Manager, ORNL Lead Management Program.

- Mr. Nathan Dunn, Hazardous Material Information System Office.

- Mr. Jade Thomas, ORNL Environmental Compliance Office.

The RmSE of this facility was conducted for LMES under contract by:

Advanced Sciences, Inc.

800 Oak Ridge Turnpike, Suite C-102

Oak Ridge, TN






\section{DISTRIBUTION}

1. L. V. Asplund

2. T. W. Burwinkle

3. K. W. Cook

4. R. E. Eversole

5. L. L. Kaiser

6-8. D. M. Matteo (3)

9. P. T. Owen

10. L. D. Owens

11. P. A. Schrandt

12. Central Research Library

13. ER Central Doc. Mgmt. Center-RC

14. R. L. Nace, Team Leader, Fernald/Ohio Team, Office of Environmental Restoration, U.S. Department of Energy, Cloverleaf Building, EM-425, 19901 Germantown Road, Germantown, MD 20874

15. J. W. Wagoner II, Team Leader, Portsmouth/Paducah/Weldon Spring Team, Office of Environmental Restoration, U.S. Department of Energy, Cloverleaf Building, EM-424, 19901 Germantown Road, Germantown, MD 20874

16. V. F. Boston, DOE Oak Ridge Operations Office, P.O. Box 2001, Oak Ridge, TN 37831-8541

17-18. R. C. Sleeman, Director, Environmental Restoration Division, DOE Oak Ridge Operations Office, P.O. Box 2001, Oak Ridge, TN 37831-8541 (2)

19-20. Office of Scientific and Technical Information, P.O. Box 62, Oak Ridge, TN 37831 (2)

21. T. R. Conant, Advanced Sciences, Inc., 800 Oak Ridge Turnpike, Suite C-102, Oak Ridge, TN 37830-6927 